sciendo Порівняльна професійна педагогіка 8(2)/2018 Comparative Professional Pedagogy 8(2)/2018

DOI: $10.2478 /$ rpp-2018-0023

$\mathrm{PhD}$ in Pedagogy, Associate Professor, NATALIYA BHINDER

Bohdan Khmelnytskyi National Academy of the State Border Guard Service of Ukraine

Address: 46 Shevchenko St., Khmelnytskyi, 29000, Ukraine

E-mail: berestetskanat@ukr.net

\title{
MODERNIZATION OF PROFESSIONAL TRAINING OF FUTURE BORDER GUARD OFFICERS IN UKRAINE ON THE BASIS OF EXPERIENCE OF INDIAN BORDER AGENCIES
}

\begin{abstract}
The article is devoted to the analysis of modernization of professional training of future border guards considering the experience of border agencies of the Republic of India. The possibilities of its creative implementation at the educational establishments of the State Border Guard Service of Ukraine have been estimated. The topicality of the comparative analysis of professional training of border guards in Ukraine and the Republic of India has been explained with the fact that these states belong to the group of developing countries and face similar border security threats. It has been proved that it is necessary to compare the systems of professional training of border guards in both countries and to analyse the modernization characteristics implemented in the Republic of India. While researching, a wide range of various scientific methods - archival research, content analysis, generalization of scientific material, deductive method of analysis and nonparticipant observation method - has been used. It has been found out that modernization of professional training of future border guard officers concerns the changes of professional training oriented towards its adaptation to up-to-date dynamic professional and educational environment. Having analyzed the experience of Indian agency-specific educational establishments, we have come to the conclusion that the following characteristics can be implemented in the process of professional training of border guard officers in Ukraine: implementation of foreign progressive ideas, spread of universal philosophical concepts, hybrid variant of professional training, life-long training, academic autonomy and academic mobility, standardization of instructors' training, person-oriented approach, wider usage of information and communications technologies, improvement of infrastructure of educational establishments, extension of practical lessons and internship, effective usage of extra-curriculum work, blended courses, and psychological relaxation techniques.

Keywords: globalization, modernization, principles, characteristics, border guard officers, agency-specific establishment, innovative technologies, professional training.
\end{abstract}

\section{INTRODUCTION}

Currently, there is an absolute necessity to improve professional training of future experts, including border guard officers, regarding up-to-date threats, conditions of sociopolitical development, globalization processes and their response, especially in developing countries. We have focused on the comparative analysis of professional training of experts of border agencies in Ukraine and the Republic of India as they belong to the group of developing countries, face similar border security threats (border conflicts, armed clashes, frequent attempts of smuggling, drug trafficking, etc.). Similarly, Ukrainian and Indian 
sciendo Порівняльна професійна педагогіка 8(2)/2018

Comparative Professional Pedagogy 8(2)/2018

border guards accomplish their service duties in various landscapes that can cause the decrease of performance efficiency. Taking into consideration that Ukrainian and Indian border agencies have similar task profile, it is important to study experience of Indian agency-specific educational establishments. We suppose that modernization tendencies oriented towards changing will result in improvement of professional training of future border guard officers, adapt them to new conditions of dynamic professional environment, prevent negative interior and exterior factors.

\section{THE AIM OF THE STUDY}

The aim of the article is to explain the peculiarities of modernizing the process of professional training of future border guard officers in Ukraine taking into consideration the experience of border agencies in the Republic of India in order to implement them creatively in the process of training the personnel of the State Border Guard Service of Ukraine.

\section{THEORETICAL FRAMEWORK AND RESEARCH METHODS}

The modernization of professional training is a topic of many researches. A. Jha and V. Maheshwari described the concept of modernization and impact of modernization on education; S. Chandra, M. Lall, F. Rivzi, S. Sharma analyzed the change of principles of Indian higher education under impact of modernization; B. Pama and K. Saini emphasized the role of modernization for the development of military education in India; P. Agarwal, P. Altbach, S. Rajput, D. Rakshit, A. Sengupta, P. Sharma, R. Sharma, S. Sharma, P. Tamboli, E G. Tuteja, and others studied the peculiarities of methodological and organizational changes of professional training under modernization. However, we have to admit the lack of attention to the topic from the side of Ukrainian pedagogues that must be tackled. During our research, we used a wide range of scientific methods: archival research, content analysis, generalization of scientific material, deductive method of analysis and nonparticipant observation method while living in the Republic of India.

\section{RESULTS}

On the basis of the analysis of various sources (Chandra et al. (2004), Saini (2008), Sengupta et al. (2015), Tamboli et al. (2013), Tuteja (2015), Vara Prasad (2016)) we can derive a unified definition of modernization which means the process of changing towards improvement as well as an objective characteristic of modern education, a complicated procedure including qualitative and quantitative changes, acceptance of modern tools for realization of professional training in consideration of technological and scientific advances and a system of up-to-date values. Modernization takes place due to changes in technologies and social profile of community; it is intellectual, psychological, social and technological phenomenon and we can assert that modern conditions of social development (rapid change of threats, dynamic technological advances, etc.) require modernization of professional training of future experts, namely border guards.

According to V. Maheshwari (2016), modernization of education is realized in four dimensions: psychological, normative, structural, and technological. Psychological dimension means that new educational tendencies, usage of innovative approaches and teaching methods, technical aids influence attitudes of future experts can affect their motivation to professional activities. Normative dimension stands for adaptation of universal norms and values reflected in the process of professional training. Structural dimension implies the impact upon structural components on the whole and educational establishments in particular. Technological dimension of modernization stipulates for the spread of new scientific advances causing the change of methods, performance speed and results of 
professional training. As modernization is closely connected with changes, V. Maheshwari suggests the following classification of modernization changes. The first type is destruction, and it causes the elimination of some cultural values, models of behavior, tradition. The examples of such changes can be caste system elimination in India and decommunization in Ukraine. The second type refers to addition and means that the emergence of new elements in the process of professional training (e. g. students' self-governance, their participation in official meetings) causes. We consider support to be the third type of changes and they relate to the creation of new conditions or improvement of existing ones (e.g. technical aids, IT, new subjects, etc.). The fourth type deals with synthetic changes and means the creation of new elements on the basis of existing ones (Maheshwari, 2016).

The role of modernization of professional training is stipulated for recent social tendencies which are common for Ukraine and the Republic of India. They are the following: spread of globalization and integration as well as urbanization, democratization, multiculturalism, universal ethics, international cooperation in the sphere of education; formation of national identity and description of national prospects; extension and differentiation of threats; industrialization, development of information technologies, increasing role of intellectual and creative work, extension of cognitive map of future experts, orientation towards active and proactive activities; attention to individual professional formation, personal motivation, need for self-actualization (Rivzi, 2012); emergence of innovative characters of expert: flexibility, empathy, adequate self-estimation, need for life-long education, responsibility, etc.

Also, it is necessary to mention social tendencies which are typical for the Republic of India and which have a significant influence upon modernization of professional training of future experts. S. Chandra et al. (2004), A. Jha (2016), M. Lall (2005), F. Rivzi (2012), A. Sengupta et al. (2015), and S. Sharma et al. (2015) claim that they are the following: secularization and westernization of educational process; rejection of traditional caste system and emergence of new social classes in accordance with educational level; changes of participants' roles within the educational environment; social differentiation and mobility; decrease of routinization; development of creativity and critical thinking; higher requirements to future experts; increase of interpersonal communication and leadership role; need for state and agency support; mature age of majority of students studying at the agency-specific educational establishments (Pama, 2008); knowledge of English and access to huge amount of information sources and exchange programs.

The tendencies mentioned above require dynamic changes in the process of professional training of future experts of border agencies. Taking this into account, we are to analyze the principles of modernization of professional training of border guard officers in the Republic of India in order to implement them in Ukraine. First of all, it is necessary to mention reformation of the process of professional training of future border guard officers orienting towards the progressive world advances that have become possible due to globalization and integration. Today the Republic of India has preserved the principles laid by the British during the British Raj and is implementing proper elements of professional training used in the EU, USA, China, South Korea and Hong Kong (Pama, 2008) that helps to universalize education and increase the efficiency approximating national standards to international ones.

Modernization of professional training of future experts in the Republic of India makes for objective extension of philosophical concepts (materialism, rationalism, 
sciendo Порівняльна професійна педагогіка 8(2)/2018

Comparative Professional Pedagogy 8(2)/2018

secularism, humanism, positivism and optimism, patriotism and morality) that inculcates values and ethical behavior in students and contributes to the development of general and professional culture, respect to other representatives of society, teaches to honour religious and cultural traditions as well as historical customs of military community. Then special attention is drawn towards hybrid variant of education that means mixture of organizational forms, organizational and pedagogical technologies, and teaching techniques, blending of courses and topics, and revision of training programs together with representatives of border agencies and leading experts in specific spheres. The next principle touches upon the concept of life-long training because of shortage of period for usage of technologies, application of innovative equipment in the sphere of border security and implementation of new types of professional activities. To solve this problem a wide range of distant learning courses, capsule courses and cascade training programs as well as retraining and professional development courses are implemented.

We agree with the opinion of P. Tamboli et al. (2013) concerning the change of methodological principles in the process of professional training of future experts, the gradual change of teaching forms and techniques, implementation of innovative approaches, including student-oriented approach. Also, it is necessary to mention academic autonomy and partial academic independence from the border agency administration in the sphere of planning and realizing educational process (e.g. rapid changes of schedule, planning of internship, free choice of teaching methods, independent planning of participation in various scientific events, etc.). The special attention is paid towards transborder educational initiatives which are very important in the process of professional training of future border guard officers.

M. Lall (2005) and A. Jha (2016) emphasize an in-depth study of the usage of information and communications technologies, LED-displays, "smart class", e-books, massive open online courses, electronic registers, etc. and their further implementation. They obviously enhance the efficiency of professional training of border guards. This fact requires the possession of digital skills by both instructors and students. In addition to innovative technologies, infrastructure of military educational establishments is being improved in accordance with current trends. We think that this principle deals with educational visits to border detachments, demonstration and practical lessons with experienced instructors. Also, we agree that students of master programs have to participate in mutual projects with representatives of border agencies. Also, modernization of professional training of future border guard officers deals with effective implementation of selfpreparation work as it makes for increase the volumes of learning materials, information revision and formation of interpersonal skills, leadership qualities, instructor's competency. And considering the dynamics of social changes and tense conditions of service, future personnel are taught to use techniques of psychological relaxation: yoga, active sports games, dance movement method, and anger release exercises. These techniques are implemented as psychological and pedagogical innovations in the process of training of future border guards during the lessons of physical training, morning or evening exercises, extra-curriculum and independent work.

On the basis of the description of characteristics peculiar to modernization of professional training of border guards at Indian agency-specific agencies, we are to analyze the possibilities of their creative implementation in the process of training of future border guard officers at Bohdan Khmelnytskyi National Academy of the State Border Guard Service of Ukraine. The table shows the findings of the analysis. 
Table 1

\section{Creative implementation of modernization in the process of training future border guard officers in Ukraine}

\begin{tabular}{|c|c|}
\hline $\begin{array}{c}\text { Modernization characteristic } \\
\text { applied in India }\end{array}$ & Possibility of implementation of modernization characteristic in Ukraine \\
\hline $\begin{array}{l}\text { Consideration of international } \\
\text { experience }\end{array}$ & $\begin{array}{l}\text { Ukraine is oriented towards gaining experience of EU or NATO members in the } \\
\text { process of modernization of professional training of servicemen, but there is a } \\
\text { necessity to study and creatively implement the experience of countries facing } \\
\text { similar threats. Besides, it is important to study the practices of developing } \\
\text { countries in the sphere of affiliation of educational establishments and their } \\
\text { accreditation in accordance with international standards }\end{array}$ \\
\hline $\begin{array}{c}\text { Spread of universal } \\
\text { philosophical concepts }\end{array}$ & $\begin{array}{l}\text { Orientation towards Indian philosophical concepts may create a successful system of } \\
\text { professional training of future experts of border agencies. Humanism, morality, } \\
\text { patriotism are widely applied in the process of training of future border guard } \\
\text { officers in Ukraine but some elements of Indian philosophical concepts can be } \\
\text { creatively used while training personnel of the State Border Guard Service of } \\
\text { Ukraine, namely positivism, optimism, aestheticism, cosmopolitism. } \\
\text { Implementation of these ideas can be rather effective for education of future border } \\
\text { guards, inculcation of universal social values, formation of general and professional } \\
\text { culture, cross-cultural competence, orientation towards positive results of } \\
\text { professional and private life, respect to national and foreign traditions, and others }\end{array}$ \\
\hline $\begin{array}{l}\text { Hybrid variant of professional } \\
\text { training }\end{array}$ & $\begin{array}{l}\text { Creative usage of combined elements of forms for organization of professional } \\
\text { training, teaching methods, blended approach to lesson design, cross learning } \\
\text { and feedback between instructors, students and experts of active-duty border } \\
\text { agencies have a wide range of advantages and enhance the efficiency of } \\
\text { professional training significantly. }\end{array}$ \\
\hline $\begin{array}{l}\text { Life-long professional } \\
\text { training }\end{array}$ & $\begin{array}{l}\text { Design of open online courses, implementation of pre-employment, retraining } \\
\text { and professional development courses, development of e-books and usage of } \\
\text { social media tools provide effective life-long professional training which is } \\
\text { getting more important regarding dynamic changes of technological advances } \\
\text { and border security models }\end{array}$ \\
\hline $\begin{array}{l}\text { Academic autonomy } \\
\text { and academic mobility }\end{array}$ & $\begin{array}{l}\text { Higher military educational establishments in Ukraine have a sufficient level of } \\
\text { academic autonomy in the sphere of educational activities planning, choice of } \\
\text { subjects and topics for scientific research, usage of teaching aids and methods. } \\
\text { But it is important to reconsider the category of academic mobility that can } \\
\text { extend teaching personnel experience and improve the interior characteristics of } \\
\text { courses they lecture considerably }\end{array}$ \\
\hline $\begin{array}{c}\text { Standardization } \\
\text { of instructors' training }\end{array}$ & $\begin{array}{l}\text { In order to improve the process of professional training of border guards, it is } \\
\text { required to pay attention towards the methodical training of teaching staff and } \\
\text { officers-instructors working at the training centers with junior enlisted and reconsider the } \\
\text { possibility to involve the positions of teacher's assistants and scientific advisors }\end{array}$ \\
\hline Person-oriented approach & $\begin{array}{l}\text { Interactive technologies are widely used in Ukrainian educational establishments but } \\
\text { concerning the efficiency of person-oriented approach we suppose to develop } \\
\text { methodological techniques to apply interactive technologies not only during } \\
\text { practical lessons but during lectures and independent preparation hours assigning } \\
\text { special tasks designed for group work without involvement of a teacher }\end{array}$ \\
\hline $\begin{array}{c}\text { Information and } \\
\text { communications technologies }\end{array}$ & $\begin{array}{l}\text { Extension of a range of information and communications technologies being } \\
\text { used is required for enhancement of efficiency of professional training and } \\
\text { optimization of instructors' functions }\end{array}$ \\
\hline $\begin{array}{l}\text { Improvement of infrastructure } \\
\text { of educational establishments }\end{array}$ & $\begin{array}{l}\text { Renewal or construction of new buildings, classrooms, special labs, libraries, } \\
\text { hostels, hotels for visiting staff, assembly halls, cafes, rest places is an important } \\
\text { factor for inner motivation of students and instructors as well. Moreover, new } \\
\text { designs of buildings provide possibilities to implement innovative technologies } \\
\text { and technical aids }\end{array}$ \\
\hline
\end{tabular}


sciendo Порівняльна професійна педагогіка 8(2)/2018 Comparative Professional Pedagogy 8(2)/2018

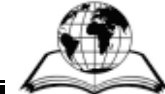

\begin{tabular}{|c|l|}
\hline $\begin{array}{c}\text { Modernization characteristic } \\
\text { applied in India }\end{array}$ & Possibility of implementation of modernization characteristic in Ukraine \\
\hline $\begin{array}{c}\text { Assigning more hours } \\
\text { to practical lessons } \\
\text { and internship }\end{array}$ & $\begin{array}{l}\text { Training of junior leaders and bachelors is considered to be practical training } \\
\text { and assigning more hours to practical and demonstration lessons, internship, night } \\
\text { trainings, camps, etc. is an integral part of professional training of future border } \\
\text { guard officers. Also, we suggest that it is important to consider the experience of Indian } \\
\text { agency-specific educational establishments which can be applied during educational } \\
\text { visits and complex war games, including participation of active-duty personnel }\end{array}$ \\
\hline $\begin{array}{c}\text { Effective usage of extra- } \\
\text { curriculum and independent } \\
\text { work }\end{array}$ & $\begin{array}{l}\text { Hours of extra-curriculum and independent work are recommended for extra } \\
\text { tasks concerning usage of special equipment, writing scientific projects, conducting } \\
\text { horizontal lessons and cross-learning programs. The role of the teacher is } \\
\text { excluded, and any student can facilitate extra-curriculum events }\end{array}$ \\
\hline $\begin{array}{c}\text { Blended courses } \\
\text { Implementation of } \\
\text { techniques }\end{array}$ & $\begin{array}{l}\text { Blended courses and blended lessons provide formation of professional skills, } \\
\text { integrated system of beliefs about future professional activities, make for } \\
\text { deepening and extension of professional knowledge, range of its application in } \\
\text { the process of accomplishment service duties }\end{array}$ \\
\hline $\begin{array}{c}\text { Considering the fact that professional activity of border guards is tense, intensive and } \\
\text { dangerous, some psychological relaxation techniques must be implemented. } \\
\text { Special attention is paid to further independent usage of psychological relaxation } \\
\text { techniques by the personnel of border agency }\end{array}$ \\
\hline
\end{tabular}

\section{CONCLUSIONS}

Thus, modernization of professional training of future border guard officers concerns the changes of professional training oriented towards its adaptation to up-to-date dynamic professional and educational environment. Having analyzed the experience of Indian agency-specific educational establishments, we have come to the conclusions that the following characteristics can be implemented in the process of professional training of border guard officers in Ukraine: consideration of international experience and implementation of foreign progressive ideas, spread of universal philosophical concepts (humanism, optimism, morality, positivism, etc.), application of hybrid variant of professional training, adoption of life-long professional training, reconsidering academic autonomy and academic mobility of teaching staff, standardization of instructors' training, implementation of person-oriented approach while teaching future border guard officers, wider usage of information and communications technologies, improvement of infrastructure of educational establishments, assingning of more hours for practical lessons and internship, effective usage of extra-curriculum and independent work, development of blended courses, and implementation of psychological relaxation techniques.

Further, we are planning to outline detailed scientific and methodical recommendations to modernize the process of professional training of future border guards at Bohdan Khmelnytskyi National Academy of the State Border Guard Service of Ukraine.

\section{REFERENCES}

1. Chandra, S. S., \& Sharma, K. R. (2004). Principles of education. New Delhi: Atlantic Publishers and Distributors.

2. Jha, A. S. (2016). Impact of modernisation on education. International Journal of Advance Research and Innovative Ideas in Education, 2 (2), 1885-1889.

3. Lall, M. (2005). The challenges for India's education system: Asia programme. London: Chatham House. 
4. Maheshwari, V. K. (2016). The concept of modernization. Retrieved from http://www.vkmaheshwari.com/WP/?p=2175.

5. Pama, B. (2008). Paradigm shift in training in the army. New Delhi: KW Publishers Pvt. Ltd.

6. Rivzi, F. (2012). Challenges of modernization of higher education. In P. Agarwal (Ed.), A Half-Century of Indian Higher Education. Essays by Philip G. Altbach (pp. 3-8). New Delhi: Sage Publication India Pvt Ltd.

7. Saini, S. K. (2008). Revamping the military training system. Journal of Defence Studies, 2 (1), 65-78. Retrieved from https://idsa.in/jds/2_1_2008_RevampingtheMilitary TrainingSystem_SKSaini.

8. Sengupta, A. (2015). Modernization of legal education in India: the interdisciplinary approach to education. Asian Journal of Legal Education, 2 (1), 57-66.

9. Sharma, S., \& Sharma, P. (2015). Indian higher education system: challenges and suggestions. Electronic Journal for Inclusive Education, 3 (4), 1-4. Retrieved from https://corescholar.libraries.wright.edu/cgi/viewcontent.cgi?referer=https://www.google.co m.ua/\&httpsredir $=1 \&$ article $=1179 \&$ context $=$ ejie.

10. Tamboli, P. M., \& Nene, Y. L. (2013). Modernizing higher agricultural education system in India to meet the challenges of 21st century. Asian Agri-History, 17 (3), 251-264.

11. Tuteja, G. S. (2015). Modernization in distance learning education system through BOOC's. In P. Sharma et al. (Eds.) Sustainable Smart Cities in India (pp. 721-730). Cham: Springer.

12. Vara Prasad, E. (2016). Education and modernization in India. International Journal of Innovative Research in Information Security, 3 (9), 82-83. 